\title{
Journal of Tropical Horticulture
}

\section{Volume 2, Number 2, October 2019}

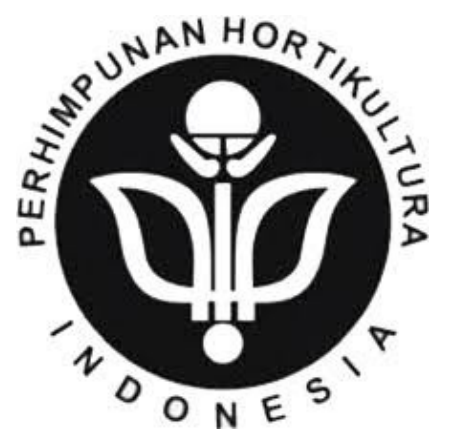

Published by:

Indonesian Society for Horticulture (Perhorti) Aceh Commissariat Website: https://jthort.org 


\section{Journal of Tropical Horticulture}

\section{Volume 2, Number 2, October 2019}

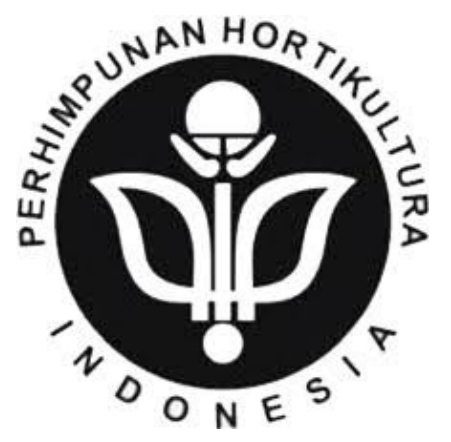

Published by:

Indonesian Society for Horticulture (Perhorti) Aceh Commissariat Website: https://jthort.org 


\section{Journal of Tropical Horticulture}

\section{About Jthort}

Journal of Tropical Horticulture (JTHort) ISSN 2622-8432 (online) DOI Prefix 10.33089/jthort by crossref is a peer-reviewed open-access international journal contains primary articles of research and review in horticulture such as fruits, vegetable, and ornamental plants also tropical biopharmaca plants. This journal is under the management of Indonesian Society for Horticulture (Perhorti) Aceh Commissariat.

Journal of Tropical Horticulture was first published in October 2018. This journal publishes its articles twice, April and October annually and receives articles from various countries within the scope of tropical plants.

Submitted papers must be written in English prepared using the JTHort Template for initial review stage by editors and further review process by minimum reviewer boards.

\section{HOW TO SUBMIT PAPER?}

The articles should be original, unpublished, and not in consideration for publication elsewhere at the time of submission to the JTHort. Every submitted manuscript to the JTHort must be written in English and follow the Author Guidelines. Please read author guidelines. Before submission, please make sure that your manuscript is prepared using the JTHort Template. If the manuscript does not meet the author guidelines or written in a different format, the article will be reject. Only submitted manuscript that meets JTHort Template will be processed further.

\section{ONLINE SUBMISSIONS}

1. Already have a Username or Password for Journal of Tropical Horticulture? Please GO TO LOGIN : http://jthort.org/index.php/jthort/login

2. Need a Username/Password? GO TO REGISTRATION

\section{http://jthort.org/index.php/jthort/user/register}

Registration and login are required to submit items online and to check the status of current submissions.

If you have any specific questions, please do not hesitate to contact us at: editor@jthort.org or editor.jthort@gmail.com

\section{PUBLISHED BY}

Indonesian Society for Horticulture (Perhorti) Aceh Commissariat

Website : http://www.jthort.org/index.php/jthort/

E-mail : editor@jthort.org or editor.jthort@gmail.com 
ISSN 2622-8432 (online)

\section{Journal of Tropical Horticulture \\ EDITORIAL TEAM}

\section{EDITOR-IN-CHIEF}

Ismadi, Department of Agroecotechnology, Universitas Malikussaleh, Aceh Utara, Indonesia

MANAGING EDITOR

Dewi Sartika Aryani, Department of Agroecotechnology, Universitas Malikussaleh, Aceh Utara, Indonesia

\section{EDITORIAL BOARDS}

BORSAI Orsolya, [Researchers ID: C-3983-2015] Department of Horticulture, University of Agricultural Sciences and Veterinary Medicine Cluj-Napoca, Romania

Abdul Mujib, [Scopus ID: 13407929400] Department of Botany, Jamia Hamdard University, New Delhi, India

Deden Derajat Matra, [Scopus ID: 57113720000] Department Agronomy and Horticulture, Bogor Agricultural University, Bogor, Indonesia

Muhammad Akram, [Scopus ID: 55390166400] Department of Eastern Medicine, GC University Faisalabad, Pakistan

Edi Santosa, [Scopus ID: 8790748700] Department Agronomy and Horticulture, Bogor Agricultural University, Bogor, Indonesia

Meutia Zahara, [Scopus ID: 57188840763] Department of Food, Asian Institute of Technology Thailand, Thailand

Pawan Kumar Bharti Chauhan, [Scopus ID: 56893358400] Department Research and Development, Shriram Institute Delhi, Delhi, India

Joko Ridho Witono, [Scopus ID: 19436718100] Center for Plant Conservation Bogor Botanic Gardens, Indonesian Institute of Sciences, Indonesia

Sumaiyah Abdullah, [Scopus ID: 54899820000] Department of Plant Protection, Universiti Putra Malaysia, Serdang, Malaysia

Ellina Mansyah, [Scopus ID: 37261705200] Indonesian Tropical Fruit Research Institute, Indonesia

Ehsan Zeidali, Department of Agronomy and Plant Breeding, llam University, Iran

I Made Sudiana, [Scopus ID: 35209009100] Research Center for Biology, Indonesian Institute of Sciences, Indonesia

Anil Kumar Jena, Assistant Professor (Agriculture), Department of Agriculture and Horticulture, Arunachal University of Studies, Namsai, Arunachal Pradesh, India

ASSISTANT EDITOR

Rachmawati Rusydi, Faculty of Agriculture, Universitas Malikussaleh, Aceh Utara, Indonesia Ajmir Akmal, Indonesian Society for Horticulture Muhammad Aqiel, Indonesian Society for Horticulture labal Fahrezi, Indonesian Society for Horticulture

TECHNICAL SUPPORT

Mursalin, Universitas Malikussaleh, Aceh Utara, Indonesia 


\title{
Journal of Tropical Horticulture
}

\author{
Table of Content
}

Utilization of Anthocyanin Extracted from Pletekan (Ruellia tuberosa L.) in Determination Soil pH

Olivia Damayanti Putri, Dharmi Wimi Pertiwi, Bakti Wisnu Widjajani

Application of Bio P60 and Bio T10 Alone or in Combination Against Stem Rot of Pakcoy Loekas Soesanto, Atsil Hiban, Woro Sri Suharti

Six Potential Superior Durian Plants Resulted by Cross Breeding of D. zibethinus and D. Kutejensis From East Kalimantan, Indonesia: Initial Identification

Odit Ferry Kurniadinata, Song Wenpei, Achmad Zaini, Rusdiansyah Rusdiansyah. $.45-49$

Genetic and Heritability Estimation of Water Apple (Syzygium aqueum (Burm.f.) Alston)

Fitriana Nasution, Sri Hadiati

Characteristics of Innovations in the Cultivation Process of Intensive Red Chili

Eva Wardah, Setia Budi

In-vitro Callus Induction of Durian (Durio zibethinus Murr.) Leaves Using Kinetin and 2,4-D (Dichlorophenoxyacetic acid)

Rd. Selvy Handayani, Ismadi Yunus, M. Sayuti, Endri Irawan

Morphological and Stomatal Characteristics of Two Indonesian Local Orchids

Meutia Zahara, Cho Cho Win

Farmers' And Retailers' Knowledge Level Associated with Pesticide Distribution and Application in Horticultural Production Centers in Karo Regency, North Sumatera Catur Hermanto, Rasiska Tarigan, Agustina E. Marpaung, Rina C. Hutabarat.

Study of Weeds as Traditional Medicinal Plants Used by Indigenous People of West Pasaman, Indonesia

Rizki Rizki, Nursyahra Nursyahra, Oki Fernando 
ISSN 2622-8432 (online)

\section{Journal of Tropical Horticulture}

Indexed by:

INDEX COPERNICUS

Google

C) GARUDA

Crossref

ProQuest.

EBSCOhost

5) WorldCat

(a) Scilit 